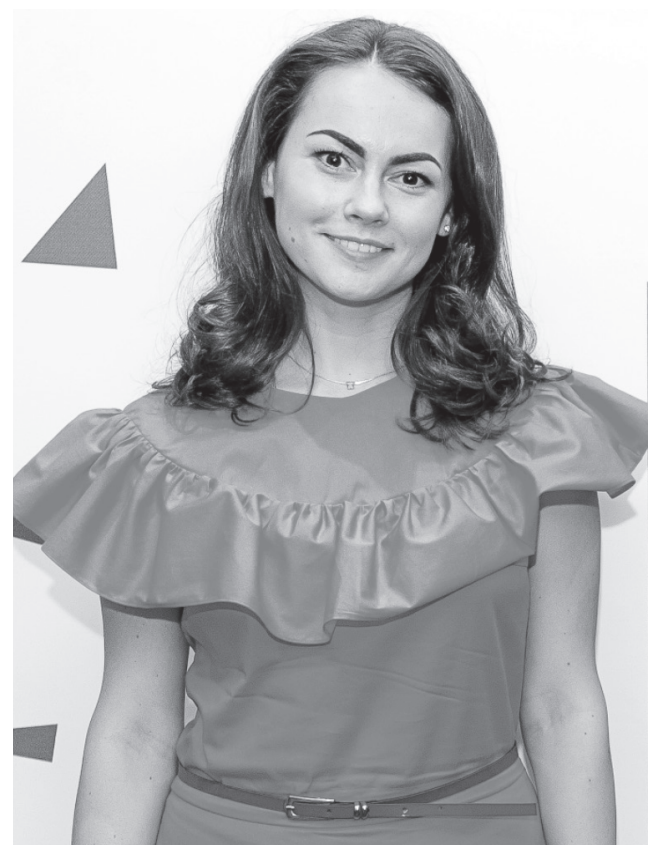

UDC: $378: 005$

Marusina Olena Sergeyevna, postgraduate of the Departmen Public Administration, Interregional Academy of Personnel Management, 03039, Kyiz, Str. Frometivska,e-mail: marusina@ukr.net

ORCID: 0000-0002-4557-5524

Марусіна Олена Сергївна, аспірантка кафедри публічного адміністрування, Міжрегіональна Академія управління персоналом, 03039, м. Київ, вул. Фрометівська, 2, е-таil: marusina@ ukr.net

ORCID: 0000-0002-4557-5524

Марусина Елена Сергеевна, аспирантка кафедры публичного администрирования, Межрегиональная Академия управления персоналом, 03039, г. Киев, ул. Фрометовская, 2, е-таil: marusina@ ukr.net

ORCID: 0000-0002-4557-5524

DOI: 10.32689/2414-0562-2018-15-5-144-156

\title{
GLOBAL ASPECTS OF THE DEVELOPMENT OF HIGHER EDUCATION IN THE MODERN WORLD AS THE MAIN DETERMINANTS OF A RADICAL CHANGE IN PUBLIC ADMINISTRATION OF THIS SPHERE
}

Abstract. The actual components of truly revolutionary changes in the sphere of higher education that are caused in the twentieth and twenty-first centuries by various objective processes - globalization, world integration and informatization, and the introduction of new technological processes and technologies into all spheres of social and spiritual production are considered. The emphasis is placed on the fact that higher education fundamentally changes its role, purpose, nature of influence on the vital activity of man and society. It is emphasized that radical changes in the phenomenon of "higher education" make it necessary to review and improve the management of this process, primarily at the state level, which requires appropriate correlations in public policy regarding higher education as a whole.

The special accents in the article are related to the following aspects of the problems of the development of higher education in the modern world: 
First, higher education, as a social institution, radically changes its purpose in connection with the change of status, participation of man in all socio-political processes. In addition to general education, professional and other training, a modern specialist should have the appropriate skills of interpersonal comattability, business qualities that fully meet the requirements of market economy.

Secondly, in the $21^{\text {st }}$ century, an essentially new revolutionary process, associated with global, globalization, integration and information phenomena, began to emerge in education. Higher education is designed to form innovative developmental human capital, emerging as a basis for continuous renewal and multiplication of such capital. Based on the widespread use of a variety of electronic and computer technology radically changing forms, technology learning, the functioning of the educational process.

Thirdly, radical changes in the essence, role, importance of higher education in human life, the functioning of society, requires a fundamental change in the nature of public administration such education. This is a new model of such a management, clarifying and working out the role and status of these processes of different subjects of such a management, especially the authorities, especially the executive, on the autonomy, democratization of higher education management, at the first level at the level of a specific institution of higher education.

Keywords: education, higher education, basic world and national foundations for the development of higher education, modern models of higher education, state regulation of the development of higher education.

\section{ГЛОБАЛЬНІ АСПЕКТИ РОЗВИТКУ ВИЩОЇ ОСВІТИ У СУЧАСНОМУ СВІТІ ЯК ГОЛОВНІ ДЕТЕРМІНАНТИ РАДИКАЛЬНОЇ ЗМІНИ ДЕРЖАВНОГО УПРАВЛІННЯ ЦІЕЮ СФЕРОЮ}

Анотація. Висвітлюються актуальні складові дійсно революційних змін у сфері вищої освіти, які у XX-XXI ст. викликані різними об'єктивними процесами - глобалізацією, світовими інтеграцією і інформатизацією, впровадженням в усі сфери суспільного і духовного виробництва новітніх технологічних процесів і технологій. Робиться акцент на тому, що вища освіта кардинальним чином змінює свою роль, призначення, характер впливу на життєдіяльність людини і суспільства. Підкреслюється, що радикальні зміни феномену “вища освіта" викликають необхідність перегляду і вдосконалення управління цим процесом, насамперед на державному рівні, що вимагає відповідних кореляцій в державній політиці щодо вищої освіти в цілому.

Особливі акценти у статті пов'язані з наступними аспектами проблем розвитку вищої освіти у сучасному світі:

По-перше, вища освіта як соціальний інститут радикально змінює своє призначення у зв'язку зі зміною статусу, участі людини в усіх суспільно-політичних процесах. Крім загальноосвітньої, фахової та іншої підготовки, сучасний фахівець повинен мати належні навички міжособистісної комутативності, ділові якості, що сповна відповідають вимогам ринкового господарювання. 
По-друге, у XXI ст. в освіті розпочався фактично принципово новий революційний процес, пов'язаний зі світовими, глобалізаційними, інтеграційними та інформаційними явищами. Вища освіта покликана формувати інноваційний розвивальний людський капітал, постає як базис постійного оновлення і примноження такого капіталу. На основі широкого використання різноманітної електронної і комп'ютерної техніки радикально змінюються форми, технології навчання, функціонування навчального процесу.

По-третє, радикальні зміни суті, ролі, значення вищої освіти у житті людини, функціонування суспільства, вимагає принципової зміни характеру державного управління такою освітою. Йдеться про нову модель такого управління, про уточнення й відпрацювання ролі і статусу у цих процесах різних суб'єктів такого управління, найперше органів влади, особливо виконавчих, про автономізацію, демократизацію управління вищою освітою найперше на рівні конкретного закладу вищої освіти.

Ключові слова: освіта, вища освіта, базові світові та національні основи розвитку вищої освіти, сучасні моделі вищої освіти, державне регулювання розвитку вищої освіти.

\section{ГЛОБАЛЬНЫЕ АСПЕКТЫ РАЗВИТИЯ ВЫСШЕГО ОБРАЗОВАНИЯ В СОВРЕМЕННОМ МИРЕ КАК ГЛАВНЫЕ ДЕТЕРМИНАНТЫ РАДИКАЛЬНОГО ИЗМЕНЕНИЯ ГОСУДАРСТВЕННОГО УПРАВЛЕНИЯ ЭТОЙ СФЕРОЙ}

Аннотация. Рассматриваются актуальные составляющие действительно революционных изменений в сфере высшего образования, которые в XXXXI ст. вызваны различными объективными процессами - глобализацией, мировыми интеграцией и информатизацией, внедрением во все сферы общественного и духовного производства новейших технологических процессов и технологий. Делается акцент на том, что высшее образование кардинальным образом меняет свою роль, предназначение, характер влияния на жизнедеятельность человека и общества. Подчеркивается, что радикальные изменения феномена “высшее образование” вызывают необходимость пересмотра и совершенствования управления этим процессом, в первую очередь на государственном уровне, что требует соответствующих корреляций в государственной политике относительно высшего образования в целом.

Особые акценты в статье связаны со следующими аспектами проблем развития высшего образования в современном мире.

Во-первых, высшее образование как социальный институт радикально меняет свое назначение в связи с изменением статуса, роли человека во всех общественно-политических процессах. Кроме общеобразовательной, профессиональной и иной подготовки, современный специалист должен иметь соответствующие навыки межличностной коммутативности, деловые качества, вполне соответствуют требованиям рыночного хозяйствования.

Во-вторых, в XXI веке в образовании начался фактически принципиально новый революционный процесс, связанный с мировыми, глобализацион- 
ными, интеграционными и информационными явлениями. Высшее образование призвано формировать инновационный развивающий человеческий капитал, выступает как базис постоянного обновления и приумножения такого капитала. На основе широкого использования разнообразной электронной и компьютерной техники радикально меняются формы, технологии обучения, функционирование учебного процесса.

В-третьих, радикальные изменения сути, роли, значения высшего образования в жизни человека, функционирования общества, требует принципиального изменения характера государственного управления таким образованием. Речь идет о новой модели такого управления, об уточнении и отработки роли и статуса в этих процессах различных субъектов такого управления, прежде всего органов власти, особенно исполнительных, об автономизации, демократизации управления высшим образованием в первую очередь на уровне конкретного учреждения высшего образования.

Ключевые слова: образование, высшее образование, базовые мировые и национальные основы развития высшего образования, современные модели высшего образования, государственное регулирование развития высшего образования.

Thesis statement. The development of modern societies, many of which carry out revolutionary transformations, the transition from post-industrial to informational state, is objectively due to the role of science and knowledge. In this case, education, the preparing of huge groups of people to fundamentally different, new, innovative models of life occupy a dominant position. Economics, politics, spirituality, other components of social life decisively depend on the essence, the specifics of the development of education, on its forming influence on the person. In this case, there are different models of education, due to world and national social processes, radically changing educational technologies, which in turn calls for a fundamental improvement of public administration, regulation of the functioning of higher education. Objectively, from the described and other problems of the functioning of higher education, its management there are many different, including controversial, points of view, which require more detailed analytical comprehension.

Analysis of recent research. Issues related to the global aspects of the development of higher education in the modern world, public administration of such education, are of great interest to domestic and foreign researchers historians, philosophers, sociologists, political scientists, psychologists, educators, representatives of other branches of knowledge. The most notable among them are the works of such domestic scientists as V. Andrushchenko, V. Bebyk, O. Valevskyi, M. Holovatyi, V. Zhuravskyi, V. Kremen, V. Lugovyi, V. Rutkevych, Yu. Surmin, and others.

Among the large number of foreign scholars there is an opportunity to appreciate the works of: E. Durkheim, 
P. Bourdieu, K. Jennis (USA), D. Floude, J. Coleman (England), V. Adamskyi, Z. Kveshynskyi, I. Bialetskyi (Poland), L. Kohan, M. Rutkevych, L. Rubina, V. Turchenko, V. Shubkin, F. Filipova, O. Yakuba (Russian Federation) and others.

There are many diverse special scientific publications that form the basis of this article. Among them there are two: Valevskyi O. Methodological Principles of the Analysis of State Policy. Philosophical thought. 2000. - № 5. - P. 62-63; Andrushchenko V. P., Soloviov V. L. Educational Policy (Review of the Agenda) K.: "MP "Lesia". - 2010. - 404 p. As O. Valevskyi writes, "the subject of the analysis of educational policy is the search of ways of optimal realization of interests of entities of political action in the sphere of education - state bodies, higher educational institutions, civil society institutions, business" (p. 62).

Among the foreign authors on such an issue is the work of Raymers F. and McGinnal N. "Competent Dialogue: Using Research to Create a World Educational Policy. - Lviv : Litopys, 2004".

In order to analyse the world and national trends in the development of education, including higher education, we took into account the works of V. Andrushchenko [11], V. Astahova [2], A. Verbytskyi [3], K. Volokitin [7], M. Holovatyi [9], T. Huzik [6], L. Karpets [7], D. Matros [8], I. Naidionov [10], Yu. Surmin [13], T. Shcherbakova [4], and others.

Among the large number of special works related to globalization, national transformational processes in the field of higher education, management of it, we refer to the works of $\mathrm{K}$. V. Korsak "World Higher Education. Comparison and recognition of foreign qualifications and diplomas / Ed. prof. G. V. Shchokin: Monograph. K.: IAPM. 1998; Hershunskyi B. S. "Philosophy of Education for the XXI: Textbook for self-education. Edition 2, revised and supplemented. M.: Pedagogical Society of Russia, 2002. 321 p."; "Course of lectures on sociology of education: Textbook for higher education institutions" / People's Ukrainian Academy. - K.: PUA Publishing House, 2003. - 424 p. etc.

Even a retrospective analysis of literature on a given issue gives grounds to argue that the valuable conceptualgeneralizing works on the problem of radical transformations in higher education and, at the same time, their "challenges" to radical change, and the improvement of public administration of higher education are still lacking. This attempt is to somewhat compensate for such a gap, to share the author's own point of view.

The objective of the study. The article examines the conceptual foundations of the development of higher education in the XXI century under the conditions of globalization, information, communication processes in order to prove that they are the ones that cause the radical change of models and mechanisms of public administration of higher education. We proceed from the fact that when developing the model of public administration of higher education at the national level, one must take into account the specifics of the socio-economic development of the country, the specific require- 
ments regarding the nature and requirements for educational and professional training of a specialist, the need to build education on innovation principles, processes related to mobility of specialists with higher education.

Results. With all the obviousness of the essence nature and content, a phenomenon of "education" in general has many, often quite different explanations. We consider that back in 1998 the Russian "Sociological Encyclopaedic Dictionary" gave a very specific and original definition of the phenomenon of "education". It is as follows: "Education is: 1) a social institution that carries out the functions of training and incorporating an individual into various spheres of society's life; 2) universal value throughout life; a set of systematic knowledge and the skills acquired by the individual independently or in the process of studying in educational institutions; 3 ) one of the indicators of the social status of the individual and the reproduction of the social structure of society" [1, c. 610]. This definition is successful and generally accepted, since it provides: the essence of education, its purpose, functions performed by education in relation to man and society. The essence, purpose and content of higher education should answer the question - why, what for, for what purpose higher education should prepare a person for life theoretically and practically right now, in the XXI century. A specialist in the modern labour market must meet the following basic requirements: 1) education and the availability of appropriate intellectual traits; 2) skills of interpersonal communication (sociability); 3) business qualities (professionalism):
- education. It is not just about the presence of a certain amount of knowledge but about the analytics of thinking, the flexibility of mind, the ability to perceive the new, the ability of constructive thinking, innovation [2-4];

- sociability. Ability not only to formulate own thoughts, but also to communicate with others, to cooperate with them in the theoretical and practical terms $[5 ; 6]$;

- professionalism. In addition to knowledge of the case, it needs also appropriate, inherent in a particular kind of action, skills and is related to business, organization, ability to quickly respond to different situations, etc. [7;8].

A significant number of specialists from various fields of knowledge now speak about the fact that in education, especially in higher education, in the $21^{\text {st }}$ century a particular revolutionary process began. Yu. Surmin, a wellknown Ukrainian expert in public administration, believed that the main features of such a revolution were:

1. The transformation of education into the main source of wealth of society. This is the place, they say, because it is human capital that becomes the main wealth of post-industrial societies. In the economy, according to the scientist, the so-called "extra value", which is provided by knowledge, information, intelligence, plays a very significant role. Actually, knowledge itself becomes a product.

2. Countries of the world are moving from the current issue of specialists to the "production" of their small "series" or even individually. At the same time, the more important quality of education is its flexibility, the ability to "re-equipping". This situation applies 
both to education on the whole, and to its specialist product. Education is becoming more human-centric.

3. We have a transition from the assimilation of information to the formation of qualities that are extremely necessary for the creative activity of the individual. An important task of education in this case is the preparation of a creative thinker, an innovative person with a great potential and ability to continuous self-development and self-improvement.

4. A continuous computerization of training, which drastically changed the whole education system, training a specialist, is observed. There appeared fundamentally new, progressive technologies of learning that essentially predetermined the role of both teacher and student in the learning process.

5 . There is an increase in the overall role of education in society, the expansion of its scale and, simultaneously, the strengthening of the impact of education on all spheres of functioning of society, on the comprehensive process of socialization of a person (personality) throughout his/her life.

6 . There is an increase in society's expenditures on education, studies, with the simultaneous growth of the return on it. In this circumstance, education becomes one of the most profitable spheres of social life, becoming in many ways an independent and selfsufficient factor of social development.

7. As never before, education concentrates many progressive innovations, forms an innovative, developing human capital, and therefore becomes a powerful source of constant renewal and multiplication of such capital. Countries with better education also have relevant leadership positions at the world level in all spheres of life.

8. The multiplicity, multi-variance of education as a social phenomenon, the multi-level of education grow, the possibilities of choosing educational systems and stages of the process of learning expand considerably.

9. The humanization of education, its orientation towards a particular person, its predispositions, abilities, and talent are quite noticeable. Education becomes more targeted, becoming human oriented.

10. In many cases, one ensures the continuity of education, which a person will receive not once in a lifetime, but as a form of education for continuing education (throughout life). In addition, with the help of an intensive information environment, a person gets opportunities for a permanent and powerful update of his/her knowledge within a rather short time. The periods of intense productive activity of a person are increasingly confined to the periods of his/her training, professional retraining, advanced training.

11. The significant technification of education based on the widespread use of a variety of electronics and computer equipment is important. As a result, there are great opportunities for the development of various forms of distance, home-based education [6, p. 318].

This is not just about the corresponding structural, meaningful changes in education, but the fundamental transition from classical education to the so-called post-classical, which is often referred to as the revolution in education.

In general, when one talks about the revolution in the education system, 
one takes into account the cultural, technological, informational and other changes inherent in the globalization process that began to develop especially after the end of the Second World War and accelerated too much in the last decades of the twentieth century.

A great deal of attention to the development of education systems is a global process, and therefore experts from UNESCO, the World Bank, the Council of Europe and scholars from many countries study how extension of the coverage of young people in secondary and higher education, and consequently the increase in the average duration of training for new generations, influences the increase of gross national product (GNP) and human potential of countries. Thus, different authors and analysts are not unanimous in terms of GDP growth, but the positive impact of the expansion of secondary and higher education on economic indicators of the countries is undeniable, as evidenced by the rapid progress of development not only of the countries of Eastern and Southern Asia, but also of Europe and other continents. One should study this question, however, even more deeply. We also take into account the fact that under the conditions of global integration, global processes, science and education play a great coordinating, unifying role. The fact is that global society involves the unity of the basic principles of organization of training, retraining and professional development of personnel in order to implement common standards of training specialists, to ensure their global mobility through equal conditions for training, internships and employment in any country of the world for all, independently from nationality.

In this case, we also substantiate the thesis that the globalized world largely uses directly education and science for integration, unifying processes in the relations between countries, states. It is necessary to create the most favourable conditions for student mobility, to give him/her the opportunity to study in different countries in the chosen specialty. Here it is worth mentioning the following thesis as well. The wellknown American economist, R. Barro, managed to analyse the influence of the educational complex itself on the development of more than 100 countries at the end of the $21^{\text {st }}$ century. At the same time, he substantiated the idea that the increase in the absolute duration of youth education influenced to a lesser extent directly the economic and social progress of the countries than the improvement of the study of natural sciences and mathematics. Apparently, therefore, the countries of the European Union jointly decided to intensify the programs of the development of natural and mathematical education, to stimulate the choice of young people of exact sciences for study at universities, to expand the training of young scientists in the most promising fields - nano-science, high technologies, computer science, etc.

Despite the importance of the support and development of exact sciences, it is more expedient, not to absolutize the value of any one indicator of the education system, but to develop such a system as a whole, designed to provide professional competence and bring to the labour market all representatives of new generations. At the 
same time, it is also necessary to optimize the structure of the educational system and to increase the duration of studies in secondary and high schools, although there is no clear view in this regard.

The main trends in the development of modern education in general and higher education directly are the following:

- expansion of the network of educational systems in order to ensure the right to education for all those wishing (the possibility and equal chances for every person to get education in an educational institution of any type, regardless of national and racial affiliation);

- formation of continuous education (education for all life), accompanying a person in the process of his personal business, professional life;

- a clearly expressed process of substantial democratization of the educational system, the sequence of its degrees and levels, the provision of maximum autonomy for educational institutions, the development of student self-government;

- significant influence of globalization, integration and other processes and socio-economic, political factors on education (cultural and educational monopoly of certain ethnic minorities, paid forms of training, etc.), etc.

In the above mentioned and other progressive circumstances, higher education is:

- a dominant condition for the progressive development of any society. It was and remains an integral part of the social policy of any state. An explanation of this component gives an understanding of the essence, purpose of social policy. This is: "the creation of conditions for meeting the social needs and interests of people, support, protection, correction and rehabilitation of individual citizens and social groups, as well as the development (socialization) of a person" [9, p. 615].

- as the dominant component of the productive, spiritual life of society, education as a whole, and higher education, above all, - performs three main functions: a) human-oriented (providing a certain level of knowledge of the person (personality), literacy, formation of the corresponding state of the emotional-volitional sphere of a person, his/her behavioural orientations, readiness to perform various social roles, b) technological - providing a "base of life", forming skills and abilities of labour, public, economic, professional and other human activities; c) humanistic - the comprehensive education of a person, the formation of high morality, culture, understanding the priorities of universal values (life, work, person himself/herself, nature), etc.

The unity of such functions is direct and complex, since radical changes in the system of higher education in the last decades of the twentieth century were caused by:

- a huge and noticeable demographic explosion of the late 40s of the twentieth century, which caused an increase of, for example, students almost three times, essentially influencing migration processes, which in turn requires an unprecedented student mobility;

- a global increase of scientific and other information, which in turn affected the scale of production mobility (the emergence of new professions, specializations), etc. 
In the second half of the twentieth century, UNESCO formulated the main ideas for the development of education, which until now have been and remain the dominant in many, especially developed, countries of the world. They are:

- integration. Education, educational systems not only of individual countries, continents but also of the planet Earth as a whole, can develop positively only by borrowing the best assets, integrating into one another;

- humanization. Education should serve humane development of mankind, ensure the fulfilment of its best hopes;

- differentiation. In all the unity, the integration, domestic education systems must necessarily take into account national aspects (history, culture, traditions, etc.);

- individualization. Education should be as much as possible focused on the personality (natural abilities, talent, psychology, etc.);

- democratization. This is a broad and multifaceted process, including democratization in the management of education in general, higher education directly [10, p. 54].

Ukrainian philosopher V. Andrushchenko, political scientist M. Holovatyi, sociologist $O$. Balakirev and many other representatives of various social sciences emphasize that particular thesis that modern man has and should have a spiritual core, which is provided exclusively by education. A modern person, as V. Andrushchenko says, is spiritual and the core of his/her life is spiritual [11, p. 6], and L. Karpets argues that "today it becomes increasingly clear that the classical model of education is an important prerequisite for the formation of an economic ap- proach to the study of human behaviour and needs a fundamental revision, since it no longer meets the requirements that are put forward to education by modern society and production" [12, p. 173].

In the National Doctrine of the Development of Education in Ukraine among the priority directions of such development are highlighted:

- personal orientation of education (its human-centricity);

- continuous improvement of the quality of education, updating its contents and forms of organization of educational process in accordance with real needs of society;

- development of systems of continuous education (education throughout life);

- close combination of education and science, the development of distance education;

- constant introduction of new information technologies [13].

Revolutionary changes in the system of higher education in the world and in Ukraine, in particular, are largely due to the modern informatization of societies, the introduction of the most advanced information technologies in education. Back in 1998, the Verkhovna Rada of Ukraine adopted the Law of Ukraine "On the National Program of Informatization", in which, in a separate subsection, formulated tasks on informatization of education. It is assumed that the use of information technology in education should envisage four main levels: a) to accompany traditional pedagogical tasks; b) in connection with the need to solve pedagogical problems that arose during the informatization of societies; c) as a technological basis for 
supporting a new paradigm of education [14, p. 52].

In the world, a lot of very different, specific educational models developed and implemented, among which several of the following can be identified:

- a model of education as a statedepartmental structure. In this case, the state authorities consider the education as a somewhat specific and independent area among other public spheres, exercising public administration of this process, largely adhering to the departmental principle;

- a model of so-called "developmental education” (V. Davydov, V. Kremen, V. Fliakov, etc.). Education is considered as a system of comprehensive training, professional training, personality development;

- a traditional model of education (Zh. Kraplia, Zh. Manso, Ch. Fin, etc.). It states that the main function of education is the transfer to the younger generation of universal elements of culture;

- a phenomenological model of education (A. Combs, A. Maslow, K. Rogers). One tries to study and organize the education with the maximum consideration of social, individual psychological and other personality traits;

- a rationalistic model of education (P. Bloom, R. Gannier, B. Skinner, etc.). It is about the maximum subordination of education, preparation of a person to specific living conditions and activities in accordance with the level and status, the nature of social development;

- not an institutional model of education (P. Goodman, F. Klein, L. Bernard, etc.). It refers to the education acquired by a person actually outside the educational institution, indepen- dently, with the help of the Internet, distance education, etc. [15].

The above-mentioned education models are not "clear", rather, we have a symbiosis of several models. At the same time, if we talk about the most basic signs of modernization of higher education, then they conventionally can be divided into two main, dominant - technological and methodological. In the first case, it is about technologies of education, and in the second - on the methodological aspects of teaching and learning.

Conclusion. Summing up the consideration of the identified relevant application problem, we can make the following fundamental conclusions.

1. The revolutionary changes and transformation in higher education are global and nationally singled out, referring to the specifics of such education (history, origins, traditions, current status, etc.). At the intersection of these two aspects, there is a modernization of higher education, including the formation of a fundamentally new model of public administration of higher education.

2. There are three essential, basic features of modern education in general, including higher education, that are really felt in the process of modernization of modern societies. First: education is becoming more and more mass, accessible, getting rid of signs of elitism. Second: the fundamental change is the universal, general civilization purpose of education. At the forefront is the compulsory education, its continuity. The third feature is related to the change in the technology itself, professional training (introduction of new technologies, information systems, etc.). 
3. The overwhelming majority of researchers in various aspects of educational development converge on the fact that modern education, as never before, requires state regulation of its development. S. G. Stetsenko writes in particular, "The state is regulating this sphere with agencies and organizations that make up the system of administrative and legal regulation in the field of education" [16, p. 410]. He also classifies these administration entities as the executive-managing and advisory bodies. If one talks about such education authorities in modern Ukraine, the first group includes the Parliament, the President of Ukraine, the Cabinet of Ministers of Ukraine, Ministry of Education and Science of Ukraine, HAC (former), local administrations and the various local self-government bodies. The second group are Board of the MESU, various public councils under the MESU, and Community boards, Pan-Ukrainian Congress of Educators (last 15 years it is not held in Ukraine), the General Meeting of Educators in regions of Ukraine, in some higher educational institutions, pedagogical councils of educational institutions, etc.

It should be noted that the presence of the above-mentioned administrative structures in the field of education, its management varies in different countries. Even the central government education body is the ministry, part of some ministry (for example - the Ministry of Education, Youth and Sports), State Committee etc.

\section{REFERENCES}

1. Sotsyolohycheskyj entsyklopedycheskyj slovar (1988). [Sociological Ency- clopedic Dictionary], Prohress, Moskow, Russia.

2. Astakhova V. I. (2002), "New trends in the socio-economic development of Ukrainian higher education and the tasks of Ukrainian politics", Pedahohika i psykholohiia, vol. 3, p. 15-18.

3. Verbyts'kyj A.A. (1991), Aktyvnoe obuchenye v vysshej shkole: kontekstnyj podkhod [Active learning in higher education: contextual approach], Vyssh. Shk., Moskow, Russyia.

4. Scherbakova T. K. (2003), "Teacher training in the university: the possibilities of creating a model", Standarty y monytorynh v obrazovanyy, vol. 1 . p. 53-57.

5. Huzik T. A. (1999), "Role of the principle of role perspective in the school process", Zaprovadzhennia suchasnykh tekhnolohij navchannia v KNEU. P. 137-139.

6. Surmyn Yu. P. (2000), "University management as a means of implementing the requirements of the educational revolution in universities", Sotsiolohichna nauka i osvita v Ukraini.

7. Volokytyn K. P. (2000), "Modern information technologies in quality management of education", Ynformatyka y obrazovanye, vol. 8, p. 32-36.

8. Matros D. (2000), "Management of the quality of education based on new information technologies and educational monitoring". Narod. obrazovanye, vol. 8, p. 75-85.

9. Holovatyj M. F., Panasiuk M. B. (2005), Sotsial'na polityka i sotsial'na robota [Social policy and social work], Terminol.-politol. sl., IAPM, Kyiv, Ukraine.

10. Najd'onov I. M. (2010), "Problems of modernization of educational efficiency", Osvita u XXI stolitti: shliakhy rozvytku, MAUP, DP "Vyd. dim "Personal", p. 54-57.

11. Andruschenko V. P. (2007), "The spiritual essence of education", Vyscha shkola Ukrainy, vol. 31, № 24, p. 5-10. 
12. Karpets' L. A. (2011), "Stratehichni tsili filosofii osvity", Filosofiia i politolohiia v konteksti suchasnoi kul'tury, vol. 1, № 1, p. 172-182.

13. The Verkhovna Rada of Ukraine, (2002), The Decree of the President of Ukraine "About the National Doctrine of Education Development Pro natsional'nu doktrynu rozvytku osvity”, available at:. http://zakon5.rada.gov.ua/laws/ show $/ 347 / 2002$

14. Holovko B. A. (2004), Reformuvannia vyschoi osvity u protsesi demokratyzatsii ukrains'koho suspil'stva [Reform of higher education in the process of democratization of Ukrainian society], Vydavnycho-polihrafichnyj tsentr Kyivs'kyj universytet, Kyiv, Ukraine.

15. Fitsula M. M. (2010), Pedahohika vyschoi shkoly [Pedagogy of high school], Akademvydav, Kyiv, Ukraine.

16. Stetsenko S. H. (2007), Administratyvne pravo Ukrainy [Administrative Law of Ukraine], Atika, Kyiv, Ukraine.

\section{СПИСОК ВИКОРИСТАНИХ ДЖЕРЕЛ}

1. Социологический энциклопедический словарь. - М.: Прогресс, 1988. $1021 \mathrm{c}$.

2. Астахова B. I. Нові тенденції в соціально-економічному розвитку української вищої школи і завдання української політики // Педагогіка і психол. - 2002. - № 3. - С. 15-18.

3. Вербицький А. А. Активное обучение в высшей школе: контекстный подход. - М.: Высш. шк., 1991. - 212 с.

4. Щербакова T. К. Подготовка преподавателя в вузе: возможности создания модели // Стандарты и мониторинг в образовании. - 2003. № 1. - C. 53-57.

5. Гузік T. А. Роль принципу рольової перспективи в навчальному процесі вищої школи // Запровадження сучасних технологій навчання в КНЕУ, 1999. - C. 137-139.
6. Сурмин Ю. П. Университетский менеджмент как средство реализации требованиий образовательной революции в университетах // Соціологічна наука і освіта в Україні: зб. наук. пр. - К.: МАУП, 2000. - 403 с.

7. Волокитин К. П. Современные информационные технологии в управлении качеством образования. Информатика и образование. - 2000. № 8. - C. 32-36.

8. Матрос Д. Управление качеством образования на основе новых информационных технологий и образовательного мониторинга // Народ. образование. - 2000. - № 8. С. 75-85.

9. Головатий М. Ф. Соціальна політика і соціальна робота: Термінол.-політол. словник / М. Ф. Головатий, М. Б. Панасюк. - К.: МАУП, 2005. $560 \mathrm{c}$.

10. Найдъонов I. М. Проблеми модернізації ефективності освіти / / Освіта у XXI столітті: шляхи розвитку. - К.: ДП “Вид. дім “Персонал”, 2010. С. 54-57.

11. Андрущенко В. П. Духовна сутність освіти // Вища школа України. 2007. - № 31 (24). - C. 5-10.

12. Карпещь Л. А. Стратегічні цілі філософії освіти // Філософія і політологія в контексті сучасної культури. - 2011. - № 1 (1). - С. 172-182.

13. Про нащіональну доктрину розвитку освіти: Указ Президента України, 2002. http://zakon5.rada.gov.ua/ laws/show/347/2002.

14. Реформування вищої освіти у процесі демократизації українського суспільства: монографія / за ред. Б. А. Головка. - К.: Вид.-поліграф. центр “Київський ун-т", 2004. - 220 с.

15. Фічула М. М. Педагогіка вищої школи: навч. посіб. - К.: Академвидав, 2010. - $456 \mathrm{c}$.

16. Стещенко С. Г. Адміністративне право України: навч. посіб. - К.: Атіка, 2007. - 624 c. 